Sains Malaysiana 50(9)(2021): 2523-2535

http://doi.org/10.17576/jsm-2021-5009-03

\title{
Synthesis and Characterization of Carboxymethyl Cellulose Derived from Empty Fruit Bunch
}

(Sintesis dan Pencirian Karboksimetil Selulosa daripada Tandan Kosong Kelapa Sawit)

\author{
Nurul Suhada Ab Rasid, MuZakkir Mohammad ZainOL \& Nor Aishah SAIDina Amin*
}

\begin{abstract}
Oil palm empty fruit bunch (EFB), a cellulose rich lignocellulosic biomass has huge potential to be utilised as a raw material for the synthesis of carboxymethyl cellulose (CMC). In this study, CMC was synthesised from EFB extracted cellulose at the optimum carboxymethylation reaction conditions. The extracted cellulose yield obtained by alkaline treatment followed by bleaching with hydrogen peroxide was $45.5 \mathrm{wt} . \%$. The cellulose structure was elucidated using thermogravimetric analysis (TGA), Fourier-transform infrared spectroscopy (FT-IR) and X-ray diffraction (XRD) patterns. Meanwhile, the synthesised CMC was characterised with FT-IR, XRD and scanning electron microscopy (SEM). The maximum degree of substitution (DS) obtained was 1.30 with the yield of 177.51 wt.\% and purity $89 \%$ determined using chemical methods at the optimum conditions of $30 \mathrm{wt} . \%$ of NaOH, $18 \mathrm{~g}$ of SMCA, $65^{\circ} \mathrm{C}, 3 \mathrm{~h}$ reaction time and less than $75 \mu \mathrm{m}$ of EFB-cellulose particle size. XRD analysis inferred low crystallinity while FTIR spectra verified the CMC structure and presence of different functional groups. The results for DS and EFB CMC yield obtained from this work were considerably higher than those reported in the literature. The synthesised EFB CMC can be further utilised in various industries such as detergent, mining, flotation, and oil and gas drilling muds applications.

Keywords: Carboxymethyl cellulose; cellulose; empty fruit bunch; oil palm; pre-treatment
\end{abstract}

\section{ABSTRAK}

Tandan kosong kelapa sawit (EFB) iaitu biojisim lignoselulosa yang kaya dengan selulosa mempunyai potensi besar untuk digunakan sebagai bahan mentah bagi sintesis karboksimetil selulosa (CMC). Dalam kajian ini, CMC telah disintesis daripada selulosa EFB yang telah diekstrak pada keadaan tindak balas karboksimetilasi yang optimum. Hasil selulosa yang diekstrak menggunakan rawatan alkali diikuti oleh pelunturan dengan hidrogen peroksida adalah $45.5 \% \mathrm{bt}$. Struktur selulosa telah diperoleh menggunakan analisis termogravimetrik (TGA), spektroskopi transformasi Fourier inframerah (FT-IR) dan corak difraksi sinar-X (XRD). Sementara itu, CMC yang disintesis telah dicirikan menggunakan FTIR, XRD dan mikroskop elektron imbasan (SEM). Tahap penggantian maksimum (DS) yang diperoleh adalah 1.30 dengan hasil sebanyak $177.51 \%$ bt. dan ketulenan $89 \%$ ditentukan menggunakan kaedah kimia pada keadaan optimum iaitu 30\% bt. NaOH, $18 \mathrm{~g} \mathrm{SMCA}$, pada $65^{\circ} \mathrm{C}$, tindak balas selama 3 jam dan saiz zarah selulosa-EFB kurang daripada 75 um. Analisis XRD menunjukkan pengkristalan yang rendah manakala spektrum FTIR mengesahkan struktur CMC dan kehadiran kumpulan berfungsi yang berbeza. Keputusan untuk hasil DS dan EFB CMC yang diperoleh daripada kajian ini jauh lebih tinggi daripada yang pernah dilaporkan. EFB CMC yang disintesis boleh digunakan seterusnya dalam pelbagai industri seperti detergen, perlombongan, pengapungan, serta penggerudian minyak dan gas.

Kata kunci: Karboksimetil selulosa; kelapa sawit; pra-rawatan; selulosa; tandan kosong kelapa sawit

\section{INTRODUCTION}

Biomass is one of the renewable energy sources that contains stored energy from the sun in green plants and other organic matter. As one of the world's leading palm oil producers, Malaysia produces a large amount of oil palm biomass, making it a promising renewable energy source. Throughout the 4.49 million hectares plantation area in Malaysia, about 17.73 million tonnes of palm oil 
and 2.13 tonnes of palm kernel oil was produced (MPOC 2015). Alongside with the palm oil production, the palm oil mills generated abundance of oil palm waste which estimated about 4.56 million tonnes palm kernel shell (PKS), 21.63 million tonnes of empty fruit bunch (EFB) and 15.73 million tonnes of mesocarp fiber (MF) (Abd Wafti et al. 2017). Since PKS and MF are traditionally used as solid fuel for steam boilers, the EFB which is high a cellulosic material, is left underutilised and is usually used for mulching due to its high acidic properties (Zafar 2019). Some are even disposed to landfills causing waste management and environmental problems (Liew et al. 2018). Therefore, it is wise to adopt the concept of 'waste to wealth' by converting the biomass, which are rich in lignocelluloses, into useful by-products such as carboxymethyl cellulose (Panwar et al. 2012).

Carboxymethyl cellulose (CMC), one of the products that could be synthesised from cellulose, has a wide industrial application. As a derivative of cellulose, CMC is an anionic linear polysaccharide that is highly viscous, nontoxic, non-allergenic and biodegradable (Huang et al. 2017). The numerous hydroxyl and carboxylic groups in CMC allow it to bind and absorb water. The production of CMC is simple, yet efficient and lowcost, involving etherification of the hydroxyl groups in cellulose under alkaline conditions (Pushpamalar et al. 2006; Rachtanapun et al. 2012). The process involves an equilibrium reaction between sodium hydroxide $(\mathrm{NaOH})$ and the $\mathrm{OH}$ groups of cellulose, followed by the formation of carboxymethyl (CM) groups using sodium monochloroacetate (SMCA). CMC is widely used in detergent, food, paper, paint, textile, pharmaceutical and cosmetic industries (Crabbe-Mann et al. 2018; Halib et al. 2009; Huang et al. 2017; Megha et al. 2018; Mousavi et al. 2017; Tongdeesoontorn et al. 2011). Water soluble cellulose derivatives, such as CMC are biocompatible and can function as thickener, binder, emulsifier, filmforming and lubricant. It is especially useful as additives in food, pharmaceutical and cosmetic industries (Joshi et al. 2015; Tongdeesoontorn et al. 2011). The usefulness of $\mathrm{CMC}$ for application is determined by its DS measurement. DS is defined as the number of substituted hydroxyl group per anhydroglucose where 3.0 is the maximum DS that can be achieved. The higher the DS the more resistant $\mathrm{CMC}$ is to degradation, which enhances its compatibility with other soluble components.

Williamson's ether reaction mechanism is used to synthesise sodium carboxymethylcellulose with side reaction (Tijsen et al. 2001). The equilibrium reaction between hydroxyl group of cellulose in sodium hydroxide produces cellulose alkoxide, followed with reaction of cellulose alkoxide with SMCA to produce carboxymethyl cellulose. The side reaction between sodium hydroxide with SMCA produces sodium glycolate and sodium chlorite. The alkalisation reaction is optimised with optimum concentration of $\mathrm{NaOH}$ to solvate its hydroxyl groups and enhances etherification reaction by breaking the hydrogen bonds increasing the DS and CMC yield (Gralén 1955).

Very few studies have been conducted on CMC synthesis from major agricultural crops in Malaysia, especially EFB. Many research related to CMC synthesis have used cellulose from paper (Joshi et al. 2015), textiles (Sheikh et al. 2015) and agricultural wastes such as wheat straw (Li et al. 2019), Thai rice straw (Sophonputtanaphoca et al. 2019), sugar beet pulp (Togrul \& Arslan 2003), corn husk (Yeasmin \& Mondal 2015), durian rind (Rachtanapun et al. 2012), almond shells (Moussa et al. 2019), cavendish banana pseudo stem (Adinugraha et al. 2005), sago waste (Pushpamalar et al. 2006), papaya peel (Rachtanapun et al. 2010), and Mimosa pigra peel (Rachtanapun \& Rattanapanone 2011). Past studies on synthesis of CMC from EFB utilised acid treatment and sodium hypochlorite bleaching as pre-treatment steps to obtain microcrystalline cellulose, both of which are not environmentally friendly, toxic and lead to low DS (Naceur Abouloula et al. 2018; Shui et al. 2017).

Hence, the purpose of this study was to investigate the synthesis of CMC using EFB cellulose. The EFB cellulose was obtained from the isolation process using sodium hydroxide and bleached with hydrogen peroxide. The influence of reaction parameters on CMC synthesis such as $\mathrm{NaOH}$ concentration, SMCA mass loading, time, temperature and particle size were explored. The physical and chemical changes of EFB cellulose to CMC were elaborated using SEM, FTIR and XRD analysis.

\section{MATERIALS AND METHODS}

\section{CHEMICALS AND SAMPLE PREPARATION}

This study used chemicals such as sodium hydroxide (NaOH) 99\%, hydrogen peroxide $\left(\mathrm{H}_{2} \mathrm{O}_{2}\right) 30 \%$, glacial acetic acid $\left(\mathrm{C}_{2} \mathrm{H}_{4} \mathrm{O}_{2}\right)(99 \%)$, methanol $(99 \%)$, isopropyl alcohol (99\%), ethanol (99\%) and commercial carboxymethyl cellulose (99\%), all manufactured by Merck, Germany. Meanwhile sodium monochloroacetic acid $\left(\mathrm{NaClCH}_{2} \mathrm{CO}_{2} \mathrm{H}\right) 99 \%$ was purchased from Nacalai Tesque, Japan and hydrochloric acid ( $\mathrm{HCl}$ ) 37\% was 
purchased from Qrec, Malaysia. Empty fruit bunch (EFB) was obtained from a palm oil mill located at Bukit Tongkat, Kluang, Johor, Malaysia. The EFB was shredded and dried in the oven at $105^{\circ} \mathrm{C}$ for $24 \mathrm{~h}$ to remove excess moisture and prevent microorganism growth.

\section{ISOLATION OF $\alpha$-CELLULOSE}

EFB was ground into powder using a laboratory blender (Waring, USA) and sieved into 300 to $500 \mu \mathrm{m}$ particle size. Ground EFB (10 g) was mixed with $100 \mathrm{~mL}$ of $10 \%$ (w/v) $\mathrm{NaOH}$ solution and heated at $100{ }^{\circ} \mathrm{C}$ for $3 \mathrm{~h}$. The slurry was washed and filtered with distilled water and dried in the oven at $60{ }^{\circ} \mathrm{C}$ for $24 \mathrm{~h}$ to obtain cellulose fibers. The fibers were bleached with hydrogen peroxide $(30 \%)$ at a temperature of $80{ }^{\circ} \mathrm{C}$ for $3 \mathrm{~h}$. The $\alpha$-cellulose was obtained after washing thoroughly with distilled water and ethanol to remove impurities and excess lignin. After filtration and drying in the oven at $100{ }^{\circ} \mathrm{C}$, the $\alpha$-cellulose was ground and sieved to a size of $<75,75<\mathrm{x}<125,125$ $<\mathrm{x}<300,>300 \mu \mathrm{m}$. The cellulose powder was packed in a polyethylene bag until it was ready to be used.

The characteristics of the extracted cellulose and raw EFB were characterised using FT-IR spectroscopy, TGA, and XRD. The FT-IR spectroscopy (Perkin-Elmer spectrum GX FT- IR system, USA) was used to detect major functional group in the extracted cellulose and the absorption mode was recorded in the range of 4000$750 \mathrm{~cm}^{-1}$ using ATR type. SmartLab X-ray powder diffractometer (Rigaku, USA) was operated using $2 \theta=10^{\circ}-60^{\circ}$ to obtain the XRD pattern of cellulose sample. A TGA System (Mettler Toledo, Switzerland) was used to obtain TGA and DTG of cellulose at temperature ranging from $30{ }^{\circ} \mathrm{C}$ to $900{ }^{\circ} \mathrm{C}$ at a heating rate of $10^{\circ} \mathrm{C} /$ min under nitrogen atmosphere.

\section{CARBOXYMETHYL CELLULOSE (CMC) SYNTHESIS}

The CMC synthesis procedure is in accordance to the procedure obtained by (Rachtanapun et al. 2012). First, $15 \mathrm{~g}$ of EFB cellulose was mixed with $50 \mathrm{~mL}$ of 10 to $40 \%$ $(\mathrm{w} / \mathrm{v}$ ) aqueous $\mathrm{NaOH}$ in $450 \mathrm{~mL}$ iso-propanol at ambient temperature for $1.5 \mathrm{~h}$ to perform the alkalisation reaction. Next, SMCA loading ( $15 \mathrm{~g}$ to $24 \mathrm{~g}$ ) was pre-dissolved in $10 \mathrm{~mL}$ isopropanol before it was added into the mixture for etherification reaction. The solution was heated at reaction temperature of 45 to $75^{\circ} \mathrm{C}$ for 1 to $4 \mathrm{~h}$ and upon completing the etherification reaction the slurry was filtered. The filtrate was suspended in $100 \mathrm{~mL}$ of methanol and neutralised with $10 \mathrm{~mL}$ of glacial acetic acid to form yellowish solid product. The solid product was washed five times with $50 \mathrm{~mL}$ of ethanol followed by one-time wash with absolute methanol to remove sodium glycolate and chloride and then dried in the oven at 60 ${ }^{\circ} \mathrm{C}$ for $3 \mathrm{~h}$.

\section{DETERMINATION OF DEGREE OF SUBSTITUTION (DS}

The degree of substitution (DS) of carboxylic group in carboxymethyl cellulose is the average number of hydroxyl group in a glucose monomer unit within the cellulose polymer which have been substituted by carboxymethyl groups. In this study, absolute values of DS were determined by potentiometric titration. CMC $(1.0 \mathrm{~g})$ was stirred with $95 \%$ ethanol $(50 \mathrm{~mL})$ for $5 \mathrm{~min}$ before $5 \mathrm{~mL}$ of $2 \mathrm{M}$ nitric acid was added under continuous stirring for $10 \mathrm{~min}$ at room temperature. The mixture was heated until boiling for $30 \mathrm{~min}$ and left to settle. The acid and salts contained in the mixture was removed by filtration and washing with hot $95 \%$ ethanol $(100 \mathrm{~mL})$ and absolute methanol, followed by drying at $70{ }^{\circ} \mathrm{C}$ for $3 \mathrm{~h}$. CMC $(0.5 \mathrm{~g})$ was mixed with $100 \mathrm{~mL}$ of distilled water and stirred. Next, $25 \mathrm{~mL}$ of $0.5 \mathrm{M}$ sodium hydroxide was added into the mixture and boiled for $20 \mathrm{~min}$. The solution was titrated with $0.3 \mathrm{M}$ hydrochloric acid, until the phenolphthalein indicator turned from purple to colorless. The DS of CMC was determined using (1) and (2) (Bono et al. 2009) followed the ASTM D 1439-94.

$$
\begin{aligned}
& A=\frac{B C-D E}{F} \\
& \text { Degree of substitution, } D S=\frac{0.162 A}{1-(0.058 \mathrm{~A})}
\end{aligned}
$$

where $\mathrm{A}$ is the milliequivalents of consumed $\mathrm{HCl}$ per gram of specimen; $\mathrm{B}$ is the volume of $\mathrm{NaOH}$ added; $\mathrm{C}$ is the molarity of $\mathrm{NaOH}$; $\mathrm{D}$ is the volume of consumed $\mathrm{HCl}$; $\mathrm{E}$ is the molarity of $\mathrm{HCl}$ used; $\mathrm{F}$ is the $\mathrm{CMC}$ in grams; 162 is the molecular weight of the anhydrous glucose unit and 58 is the net increment in the anhydrous glucose unit for every substituted carboxymethyl group.

\section{YIELD MEASUREMENT}

The yield of CMC was calculated using (3) by dividing the weight of dried CMC with weight of dried cellulose.

Yield of CMC (wt.\%) $=\frac{\text { Weight of dried CMC }(\mathrm{g})}{\text { Weight of dried cellulose }(\mathrm{g})} \times 100 \%$ (3) 


\section{PURITY OF CMC}

The purity test was adopted from elsewhere (Golbaghi et al. 2017). The synthesised CMC (DS=1.30) was washed with $80 \%$ ethanol and absolute methanol for several times to remove the by-products of $\mathrm{NaCl}$ and sodium glycolate. Then, $2 \mathrm{~g}$ of the precipitate was added in 50 $\mathrm{mL}$ of distilled water at $80^{\circ} \mathrm{C}$ and stirred until dissolved. The solution was centrifuged at $4000 \mathrm{rpm}$ and the solid precipitate was removed. The solution was mixed with 50 $\mathrm{mL}$ pure acetone to recover $\mathrm{CMC}$. Then, the $\mathrm{CMC}$ obtained was filtered, dried at $70{ }^{\circ} \mathrm{C}$, and its purity determined using (4).

$$
\text { Purity }(\%)=\frac{\text { Weight of dried residue }}{\text { Weight of specimen used }} \times 100
$$

\section{CHARACTERISATION OF CMC PRODUCTS}

The CMC obtained was characterised using FT-IR, SEM, and XRD. All the FTIR spectra were recorded on a Perkin-Elmer spectrum GX FT-IR system (Perkin-Elmer, USA) to confirm the presence of functional groups in the IR spectrum. The spectra were measured with ATR type in the wavenumber range of $750-4000 \mathrm{~cm}^{-1}$. The scanning electron microscope (SEM), SEM-5410 LV (Jeol, Japan) with $500 \mathrm{X}$ magnification was used to analyze the morphology of EFB cellulose, EFB CMC and commercial CMC. The XRD patterns of the products were recorded on a SmartLab X-ray powder diffractometer (Rigaku, USA) using $2 \theta=10^{\circ}-60^{\circ}$ at a scan rate of $5 \%$ min. The solubility of the CMC was observed by adding $5 \mathrm{~g}$ of CMC into $50 \mathrm{~mL}$ of distilled water. The $\mathrm{pH}$ of the CMC was determined using $\mathrm{pH}$ meter (Mettler Toledo, Switzerland) in the solution of $5 \mathrm{~g}$ of $\mathrm{CMC}$ and $50 \mathrm{~mL}$ distilled water.

\section{RESULTS AND DISCUSSION}

\section{CELLULOSE EXTRACTION AND CHARACTERIZATION}

The $\alpha$-cellulose content of EFB after alkaline treatment and bleaching process was 45.5 wt.\%. The differences between the raw EFB and the extracted cellulose powder were as seen in the FTIR spectra presented in Figure 1(a). The major peaks of extracted cellulose were more intense compared to raw EFB due to the breakdown of biomass structure in the alkalisation and oxidation process causing most of the lignin to be removed. The main changes in the functional groups were detected in the region from 1800 to $1000 \mathrm{~cm}^{-1}$. The band at 1515 $\mathrm{cm}^{-1}$ indicating aromatic rings and $1240 \mathrm{~cm}^{-1}$ representing ether linkage had disappeared from EFB cellulose spectra mainly due to the breakdown of lignin. The sharp peak around $1100 \mathrm{~cm}^{-1}$ exhibited the characteristics of cellulose ethers, which indicated the presence of C-O-C bonds, while the increase in band around 2800 to $2900 \mathrm{~cm}^{-1}$ indicated the presence of $\mathrm{CH}$ and $\mathrm{CH}_{2}$ of the cellulose. These IR spectra were consistent with the results regarding raw EFB and EFB cellulose (Liu et al. 2006; Palamae et al. 2017).

The thermal behaviour of extracted EFB cellulose, selected CMC with the highest DS of 1.30 and commercial CMC was analysed by TGA recorded in nitrogen atmosphere from 30 to $900^{\circ} \mathrm{C}$ as shown in Figure 1(b). The thermal degradation pattern was determined by many factors such as sample crystallinity, orientation and molecular weight. Based on the figure, three types of EFB cellulose degradation were involved. Starting at below 100 to $150{ }^{\circ} \mathrm{C}$, the mass loss was due to moisture vaporisation by EFB cellulose. The second degradation occurred at temperature of 150 to $300{ }^{\circ} \mathrm{C}$ with mass loss of $53.29 \mathrm{wt} . \%$ due to the decomposition of holo-cellulose by removal of hydroxyl and methyl hydroxyl groups. The third degradation occurred at temperature ranging from 340 to $665{ }^{\circ} \mathrm{C}$ with the mass loss of $19.07 \mathrm{wt} . \%$ due to the degradation of phenylpropane building block of lignin (Leal et al. 2015). The thermal decomposition of cellulose above $500{ }^{\circ} \mathrm{C}$ was attributed to burning of carbonaceous residues in cellulose leaving about $10 \mathrm{wt} . \%$ of solid residue. At above $900{ }^{\circ} \mathrm{C}$, the weight of EFB cellulose decreased compared to raw EFB due to the breakdown of lignin compound decreasing the thermal stability of EFB cellulose.

\section{OPTIMISATION OF PARAMETERS FOR CARBOXYMETHYLATION}

The production of CMC via the carboxymethylation of EFB cellulose was optimised by varying the process parameters to optimize the degree of substitution (DS). The parameters, namely sodium hydroxide concentrations, reaction time, temperature, SMCA concentration, and particle size were varied individually while keeping the other parameters constant during the reaction. Isopropanol was used as inert solvent, which acted as swelling agent for etherification and carboxymethylation reactions to enhance the production of CMC rather than glycolate formation (Joshi et al. 2015).

\section{EFFECT OF NaOH CONCENTRATION}

The effect of $\mathrm{NaOH}$ concentration (10 to $40 \%$ ) on the DS and yield of prepared CMC were as shown in Figure 2(a) 

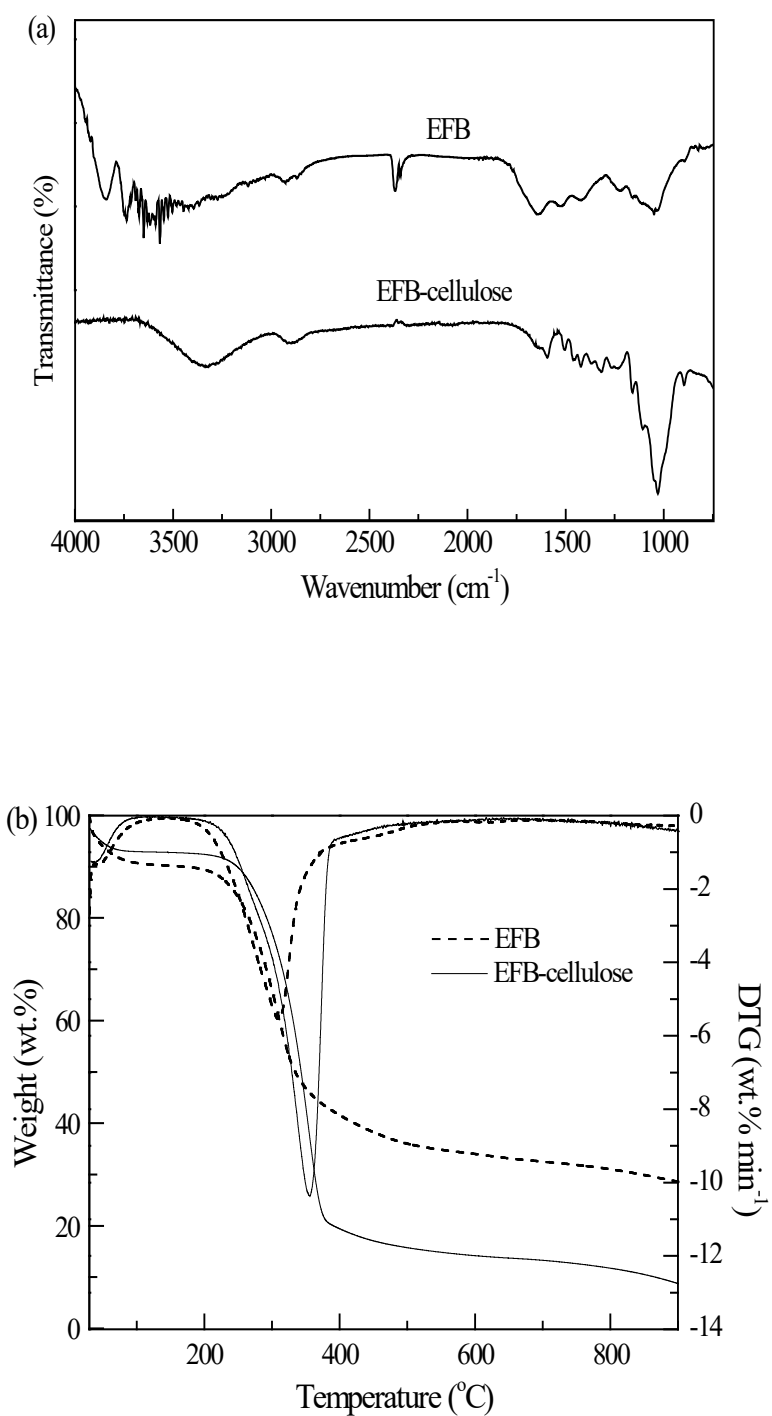

FIGURE 1. FTIR spectra (a) and TGA-DTG curves (b) of raw EFB powder and EFB cellulose

while other reaction parameters weight of SMCA (18 $\mathrm{g})$, reaction time $(3 \mathrm{~h})$ and temperature $\left(55^{\circ} \mathrm{C}\right)$ remained constant. DS increased with $\mathrm{NaOH}$ concentration until $30 \%$ and reduced drastically beyond that. The value of DS varied from 0.63 to 0.84 while the yield varied from 128 to 144 wt.\%. The maximum DS obtained was 0.84 at the following reaction conditions: $30 \% \mathrm{NaOH}$ concentration, $18 \mathrm{~g} \mathrm{SMCA}, 55^{\circ} \mathrm{C}$ temperature, $3 \mathrm{~h}$ reaction time. The increase in DS $(0.84)$ is due to the predominance of the reaction between cellulose with $\mathrm{NaOH}$ producing alkoxide.

The alkalisation reaction enhanced the accessibility and substitution of SMCA to EFB fiber by solvating the hydroxyl groups of the cellulose structure, hence increasing the DS of CMC. However, above 30\% NaOH concentration, the side reaction between $\mathrm{NaOH}$ and SMCA 
was more substantial as more $\mathrm{NaOH}$ was consumed to produce sodium glycolate and sodium chloride due to the competitive nucleophilic reaction caused by the hydroxide ions attacking the acid. The CMC obtained appeared as a yellow cake suggesting that high alkali dosage degraded CMC thus lowering the DS and yield of CMC. Generally, an increase in etherification agent dosage in the reaction feed enhances the water solubility of the resulted CMC products, due to the increased extent of etherification reactions (Joshi et al. 2015). Thus, high dosage of the alkali agent is not recommended since it will also affect the colour, solubility and purity of CMC. Instead, an optimum dosage of the etherification agent is required to attain maximum product solubility.

\section{EFFECT OF SMCA LOADING}

The effect of SMCA loading on the DS and yield of CMC was determined by varying SMCA mass from 15 to 24 $\mathrm{g}$ as shown in Figure 2(b) at constant reaction parameter of $30 \% \mathrm{NaOH}, 50{ }^{\circ} \mathrm{C}$ temperature and $3 \mathrm{~h}$ reaction time. The DS obtained was from 0.78 to 0.84 while yield ranges from 128 to 149 wt.\% owing to the increasing SMCA loading. At the optimum condition for etherification reaction between SMCA with cellulose alkoxide, the maximum DS (0.84) was achieved at $18 \mathrm{~g}$ of SMCA loading.

Low SMCA loading caused low etherification reaction between cellulose alkoxide and SMCA, thus, lowering the DS and yield of CMC. This is due to cellulose alkoxide not fully converted to CMC. However, the increase in mass of SMCA up to $18 \mathrm{~g}$ promoted the availability of the acid molecules in the proximity of the cellulose hydroxyls, thereby facilitating carboxymethylation (Barai et al. 1997). Based on Figure 2(b), further increase in SMCA concentration above $18 \mathrm{~g}$ decreased the DS and yield of CMC due to the cellulosealkoxide had fully reacted with SMCA. Thus, excess SMCA loading was not favourable since it contributed to the formation of sodium glycolate and sodium chlorite in the side reaction of SMCA with hydroxide ions. The high concentration of SMCA might hinder the etherification reaction which reduced the substitution of SMCA with cellulose alkoxide. Thus, side reaction of SMCA with hydroxide ions might take place, and reduce DS and yield of CMC. This finding was supported by other literatures related to high concentration of SMCA on CMC synthesis (Joshi et al. 2015; Varshney et al. 2006; Yeasmin \& Mondal 2015).

\section{EFFECT OF REACTION TEMPERATURE}

The DS and yield of CMC (Figure 2(c)) were evaluated by optimising the reaction temperature in the range of 45 to $75^{\circ} \mathrm{C}$ at constant condition of $\mathrm{NaOH}(30 \%)$ and SMCA $(18 \mathrm{~g})$ and $3 \mathrm{~h}$ reaction time. Maximum DS (0.84) was achieved at $55^{\circ} \mathrm{C}$ while maximum yield of $146 \%$ was obtained at $65^{\circ} \mathrm{C}$. The DS increased up to $55^{\circ} \mathrm{C}$ because of the high swelling ability which enhanced diffusion and absorption ability of SMCA into cellulose fibre at higher temperature. Unfortunately, at temperature higher than $55^{\circ} \mathrm{C}$, the $\mathrm{CMC}$ obtained conferred lower DS and yield due to thermal degradation of carboxymethyl cellulose at higher temperature. Similar trend of carboxymethylation of cellulose can be observed from previous work on different materials (Hebeish et al. 1988; Tijsen et al. 2001; Youssef et al. 1989).

\section{EFFECT OF REACTION TIME}

The effect of reaction time, determined by varying reaction time from 1 to $4 \mathrm{~h}$ with respect to DS and yield of CMC, is shown in Figure 2(d). The reaction was performed at $30 \% \mathrm{NaOH}$ concentration, $18 \mathrm{~g}$ of SMCA and $55{ }^{\circ} \mathrm{C}$. The increase in DS $(0.84)$ with respect to time might be due to the swelling ability of the cellulose. SMCA in carboxymethylation reaction could diffuse and absorb within a longer reaction time by enhancing the contact between etherifying agents and cellulose (Barai et al. 1997; Yeasmin \& Mondal 2015). The yield of CMC was not significantly affected by reaction time. However, DS decreased at reaction time longer than 4 $\mathrm{h}$, due to the oxidative degradation of $\mathrm{CMC}$ at prolonged carboxymethylation time as similarly reported for DS of carboxymethylated waste from cotton ginning cellulose (Haleem et al. 2014).

\section{EFFECT OF PARTICLE SIZE}

Particle size play an important role in maximising the DS of prepared CMC. The cellulose particle size was varied in four different ranges of $<75,75<\mathrm{x}<125,125<$ $\mathrm{x}<300$ and $>300 \mu \mathrm{m}$. The effect of particle size shown in Figure 2(e) rendered the highest DS obtained was 1.30, with highest yield of $177.51 \%$ at the following operating parameters: $3 \mathrm{~h}$ reaction time, $30 \% \mathrm{NaOH}$ concentration and $55{ }^{\circ} \mathrm{C}$ temperature. The values for DS and yield of $\mathrm{CMC}$ decreased with particle size since a larger surface area increased the reaction between cellulose, SMCA and $\mathrm{NaOH}$ reagent, augmenting the substitution reaction 
of $-\mathrm{OH}$ groups while the carboxymethylation reaction occurs (Yeasmin \& Mondal 2015). This explained the high solubility of $\mathrm{CMC}$ at small particle size since the increase in viscosity and molecular weight of CMC were caused by $-\mathrm{OH}$ group being replaced by carboxymethyl groups in etherification reaction.
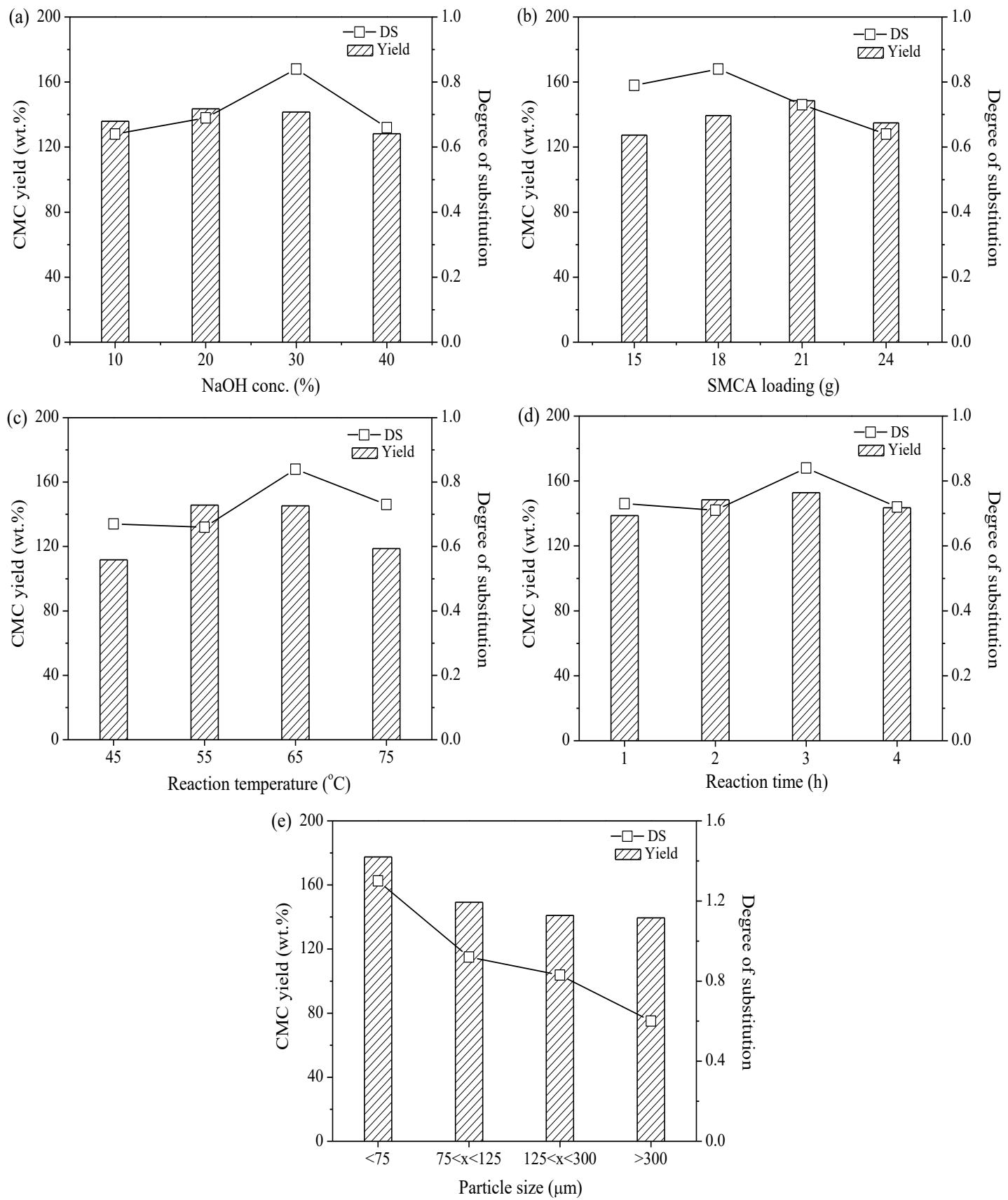

FIGURE 2. Effect of $\mathrm{NaOH}$ concentration (a), SMCA loading (b), reaction temperature (c), reaction time (d) and particle size (e) on DS and CMC yield 


\section{CHARACTERISATION OF EFB CMC}

The CMC yield was optimised by varying the reaction parameters to enhance the carboxymethylation reaction of EFB cellulose in order to get higher value of DS. DS is the most important quality indicator of the synthesised $\mathrm{CMC}$ since the industrial application of $\mathrm{CMC}$ is determined by the DS value. Previously, optimisation experiments were performed with respect to the DS values in the range of 0.4 to 2.4 (Bono et al. 2009; Haleem et al. 2014; Joshi et al. 2015). The optimised EFB CMC registered a DS value of 1.30, which was higher than other CMC studies derived from EFB as shown in Table 1. It was also highly competitive with CMC prepared from other lignocellulosic biomass sources corncob (DS= 1.02) (Jia et al. 2016), wheat straw ( $\mathrm{DS}=0.88)(\mathrm{Li}$ et al. 2019), Eucalyptus nitens (DS= 0.32) (Yáñez et al. 2018), sugarcane bagasse $(\mathrm{DS}=0.73)$ and palm kernel cake $(\mathrm{DS}=$ 0.37) (Huang et al. 2017). The variety of ranges in DS obtained by researchers might be due to the optimisation conditions used in the synthesis of CMC. Several researchers found that the high DS could be achieved using small particle size of $75 \mu \mathrm{m}$ which enhanced the collision between reactants and cellulose particle (Mondal et al. 2015). Besides, the effectiveness of the pre-treatment method for isolating cellulose might also affect the purity of cellulose, thus affecting the accessibility of the cellulose and substitution of reactant in CMC synthesis (Candido \& Gonçalves 2019).

The low DS CMC $(<0.40)$ was insoluble, while CMC with DS higher than 0.4 was soluble in water. DS value higher than 1.0 indicated highly soluble CMC proving the hydro-affinity characteristic of CMC increased with increasing DS (Yeasmin \& Mondal 2015). It was colourless, odourless and can be classified as semi-purified which could be used for detergent, mining, flotation, oil and gas drilling muds application (Mondal et al. 2015).

TABLE 1. Physical characteristic of CMC derived from EFB

\begin{tabular}{ccccc}
\hline Criteria/Reference & This study & $\begin{array}{c}\text { (Naceur Abouloula } \\
\text { et al. 2018) }\end{array}$ & (Soom et al. 2004) & (Parid et al. 2018) \\
\hline Colour & Off white & White & White & Milky white \\
Odour & Odourless & $\mathrm{n} / \mathrm{a}$ & Odourless & Odourless \\
Purity & $89 \%$ & $\mathrm{n} / \mathrm{a}$ & $85.5 \%-99.5 \%$ & $\mathrm{n} / \mathrm{a}$ \\
Form & $<0.75 \mu \mathrm{m}$ & $\mathrm{n} / \mathrm{a}$ & $\mathrm{n} / \mathrm{a}$ & $0.2 \mathrm{~mm}$ \\
pH & 7.0 & $\mathrm{n} / \mathrm{a}$ & $\mathrm{n} / \mathrm{a}$ & $6-8$ \\
DS & 1.30 & 0.60 & $0.7-0.9$ & $\mathrm{n} / \mathrm{a}$ \\
Solubility & Highly soluble & $\mathrm{n} / \mathrm{a}$ & $\mathrm{n} / \mathrm{a}$ & Soluble \\
\hline
\end{tabular}

\section{XRD ANALYSIS}

The X-ray diffraction patterns as recorded in Figure 3 for the detection peaks corresponding to the following $2 \theta$ for synthesised EFB CMC (DS=1.30) $16.62^{\circ}$ and $21.56^{\circ}$, commercial CMC $21.26^{\circ}$, EFB cellulose $22.28^{\circ}$ and raw
EFB $22.36^{\circ}$. The crystallinity of EFB decreased after alkaline pre-treatment and bleaching process due to the nature of cellulose modification after isolation process that turned the crystalline into amorphous (Candido \& Gonçalves 2019). The diffraction patterns of CMC 
exhibited a destruction in the crystalline structure of the original cellulose. All the characteristic peaks of native cellulose had almost disappeared and transformed into an amorphous phase after carboxymethylation. Amorphous phase was obtained in the synthesised EFB $\mathrm{CMC}$ as was the case with commercial CMC. This might be due to the etherification reaction of CMC broadening the cleavage of hydrogen bonds at the hydroxyl group of cellulose with SMCA as higher DS of CMC reduced the crystallinity (Palamae et al. 2017). Therefore, CMC has excellent solubility (Zhang \& Wu 1992) since lower crystallinity represents higher solubility (He et al. 2009). During carboxymethylation process, cellulose molecules are immersed in alkaline solution. The swelling of the cellulose granules exerts a tension on neighbouring crystalline of the cellulose molecules and tends to distort them. Further swelling leads to uncoiling or dissociation of their double-helical region and the breakup of their crystalline structure (Fang et al. 2002).

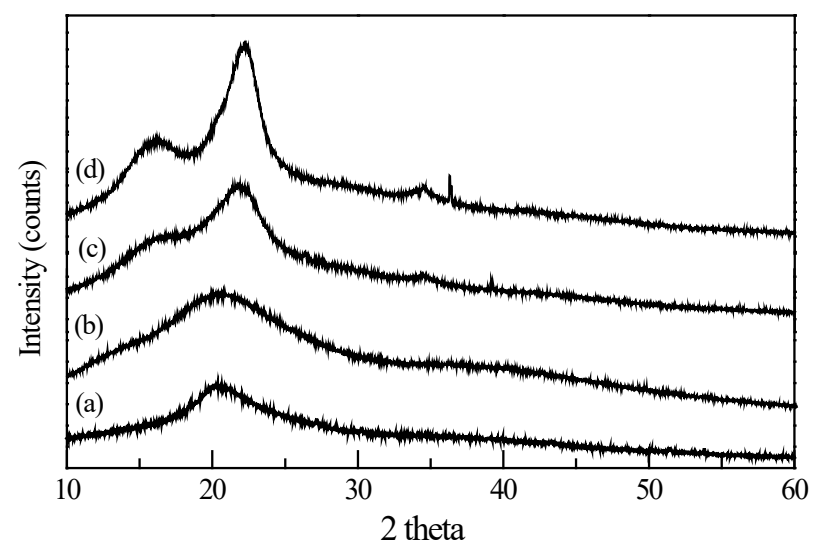

FIGURE 3. X-ray diffractogram of synthesised empty fruit bunch CMC (a), commercial CMC (b), empty fruit bunch cellulose (c) and raw empty fruit bunch $(\mathrm{d})$

\section{FT-IR ANALYSIS}

The infrared spectra could confirm the change in functional group through the etherification step. The infrared spectra of synthesised EFB CMC (DS= 1.30) was presented in Figure 4(a) and the FTIR spectra of commercial CMC was shown in Figure 4(b). The broad absorption band at 2400 to $3500 \mathrm{~cm}^{-1}$ was due to the stretching frequency of the-OH group. The band at 2920 to $2860 \mathrm{~cm}^{-1}$ was due to $\mathrm{C}-\mathrm{H}$ stretching vibration. The band around 1424 and $1322 \mathrm{~cm}^{-1}$ were assigned to $-\mathrm{CH}_{2}$ bonding and $-\mathrm{OH}$ plane bending, respectively. The presence of the new and strongest absorbance found at 1606, 1424 and $1322 \mathrm{~cm}^{-1}$ confirmed the presence of CMC and successful etherification reaction since it was not in the EFB cellulose IR spectrum. The wave number $1606 \mathrm{~cm}^{-1}$ was plot of $\mathrm{C}=\mathrm{O}$ group stretching of acetyl or carboxymethyl Carboxyl salt group had a wave number about $1600 \mathrm{~cm}^{-1}$ and $1400-1450 \mathrm{~cm}^{-1}$. These IR spectra confirmed that $\mathrm{CMC}$ had been successfully synthesised from EFB since similar trend could also be found in commercial CMC in Figure 4(b) and comparable with other studies (Joshi et al. 2015; Mondal et al. 2015). 


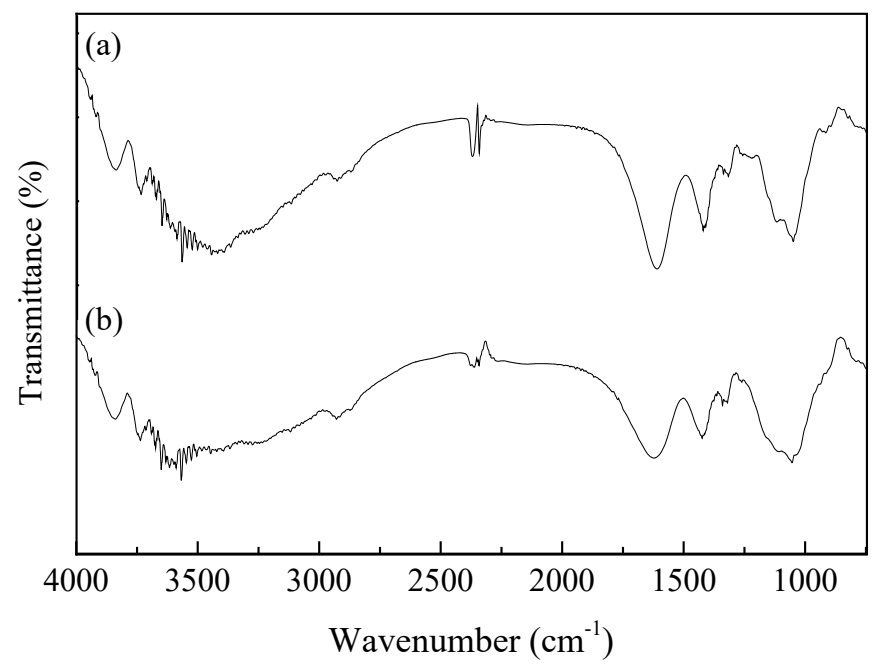

FIGURE 4. FTIR spectra and assignment of the main absorption bands of synthesized CMC (DS=1.30) (a) and commercial CMC (b)

\section{CMC MORPHOLOGY}

The SEM at 5000X magnification was shown in Figure 5, for the commercial CMC (a), synthesised EFB CMC (b) and EFB cellulose (c). The exterior surface of the EFB cellulose appeared rough and fibres twisted and ruptured, which may be caused by alkaline and bleaching process in the cellulose extraction process (Tasaso 2015). For the synthesised EFB CMC, the roughness was slightly less compared to cellulose. This result was caused by the change in the cellulose crystallinity causing an electrostatic repulsion effect between fibres and allowing the etherifying agent access to the cellulose polymer chain (Yáñez et al. 2018).
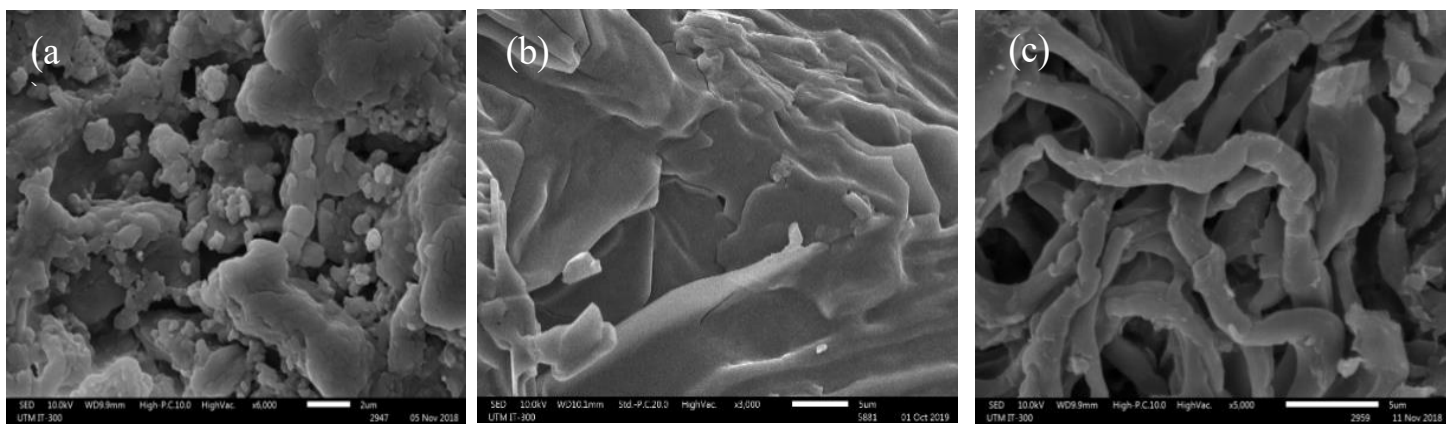

FIGURE 5. SEM micrograph at magnification of commercial CMC (6000X) (a), synthesised EFB CMC (3000X) at optimum condition (DS=1.30) (b), and EFB cellulose (5000X) (c) 


\section{CONCLUSION}

In this study, EFB CMC was successfully synthesised from cellulose obtained by alkaline pretreatment of EFB followed by bleaching with hydrogen peroxide. The results from chemical and physical characterisation of EFB CMC indicated that its properties were similar to commercial CMC. The maximum DS value for EFB CMC at 1.30 was obtained using the following optimum conditions: $<75 \mu \mathrm{m}$ EFB cellulose at $30 \%$ of $\mathrm{NaOH}, 18 \mathrm{~g}$ of SMCA, and temperature of $65^{\circ} \mathrm{C}$ in $3 \mathrm{~h}$. The smaller particle size of EFB contributed to larger surface area which increased the carboxymethylation with cellulose. The modification of cellulose to CMC was confirmed by FTIR, XRD and SEM analyses. The XRD analysis conferred CMC has lower crystallinity, while FTIR showed the functional group of CMC after carboxymethylation. The preparation method for EFB CMC is suitable to be applied to various types of lignocellulosic biomass and large-scale industrial application of CMC synthesis in the future.

\section{ACKNOWLEDGEMENTS}

The authors would like to express their sincere gratitude to Universiti Teknologi Malaysia (UTM) for the financial assistance under Collaborative Research Grant (Vote 08G63), PRGS-ICC Grant (Vote 4J325) and Professional Development Research University Post-Doctoral Fellowship (Votse 04E18 and 04E78).

\section{REFERENCES}

Abd Wafti, N.S., Lau, H.L.N., Loh, S.K., Aziz, A.A., Ab Rahman, Z. \& May, C.Y. 2017. Activated carbon from oil palm biomass as potential adsorbent for palm oil mill effluent treatment. Journal of Oil Palm Research 29(2): 278-290.

Adinugraha, M.P., Marseno, D.W. \& Haryadi. 2005. Synthesis and characterization of sodium carboxymethylcellulose from cavendish banana pseudo stem (Musa cavendishii LAMBERT). Carbohydrate Polymers 62(2): 164-169.

Barai, B.K., Singhal, R.S. \& Kulkarni, P.R. 1997. Optimization of a process for preparing carboxymethyl cellulose from water hyacinth (Eichornia crassipes). Carbohydrate Polymers 32(3): 229-231.

Bono, A., Ying, P.H., Yan, F.Y., Muei, C.L., Sarbatly, R. \& Krishnaiah, D. 2009. Synthesis and characterization of carboxymethyl cellulose from palm kernel cake. Advances in Natural \& Applied Sciences 3(1): 5-11.

Candido, R.G. \& Gonçalves, A.R. 2019. Evaluation of two different applications for cellulose isolated from sugarcane bagasse in a biorefinery concept. Industrial Crops and Products 142: 111616.

Crabbe-Mann, M., Tsaoulidis, D., Parhizkar, M. \& Edirisinghe, M. 2018. Ethyl cellulose, cellulose acetate and carboxymethyl cellulose microstructures prepared using electrohydrodynamics and green solvents. Cellulose 25(3): 1687-1703.

Fang, J.M., Fowler, P.A., Tomkinson, J. \& Hill, C.A.S. 2002. The preparation and characterisation of a series of chemically modified potato starches. Carbohydrate Polymers 47(3): 245-252.

Golbaghi, L., Khamforoush, M. \& Hatami, T. 2017. Carboxymethyl cellulose production from sugarcane bagasse with steam explosion pulping: Experimental, modeling, and optimization. Carbohydrate Polymers 174 780-788.

Gralén, N. 1955. Cellulose and cellulose derivatives (High polymers, Volume V, 2nd ed. In 3 parts). edited by Ott, E., Spurlin, H. \& Grafflin, M.W. New York-London: Interscience. Journal of Polymer Science 18(89): 443444.

Haleem, N., Arshad, M., Shahid, M. \& Tahir, M.A. 2014. Synthesis of carboxymethyl cellulose from waste of cotton ginning industry. Carbohydrate Polymers 113: 249-255.

Halib, N., Mohd Amin, M.C.I., Ahmad, I., Mohamed Hashim, Z. \& Jamal, N. 2009. Pengembungan hidrogel selulosa bakteria-asid akrilik: sensitiviti terhadap rangsangan luar. Sains Malaysiana 38(5): 785-791.

He, X., Wu, S., Fu, D. \& Ni, J. 2009. Preparation of sodium carboxymethyl cellulose from paper sludge. Journal of Chemical Technology and Biotechnology 84(3): 427-434.

Hebeish, A., Abou-Zeid, N., Waly, A. \& Higazy, A. 1988. Chemical modification of flax-cellulose via etherification, esterification and crosslinking reactions. Cellulose Chemistry and Technology 22(6): 591-605.

Huang, C., Chia, P., Lim, C., Nai, J., Ding, D.Y., Seow, P. \& Chan, E. 2017. Synthesis and characterisation of carboxymethyl cellulose from various agricultural wastes. Cellulose Chemistry and Technology 51(7-8): 665-672.

Jia, F., Liu, H.J. \& Zhang, G.G. 2016. Preparation of carboxymethyl cellulose from corncob. Procedia Environmental Sciences 31: 98-102.

Joshi, G., Naithani, S., Varshney, V.K., Bisht, S.S., Rana, V. \& Gupta, P.K. 2015. Synthesis and characterization of carboxymethyl cellulose from office waste paper: A greener approach towards waste management. Waste Management 38: 33-40.

Leal, G.F., Ramos, L.A., Barrett, D.H., Curvelo, A.A.S. \& Rodella, C.B. 2015. A thermogravimetric analysis (TGA) method to determine the catalytic conversion of cellulose from carbon-supported hydrogenolysis process. Thermochimica Acta 616: 9-13.

Li, H., Zhang, H., Xiong, L., Chen, X., Wang, C., Huang, C. \& Chen, X. 2019. Isolation of cellulose from wheat straw 
and its utilization for the preparation of carboxymethyl cellulose. Fibers and Polymers 20(5): 975-981.

Liew, R.K., Nam, W.L., Chong, M.Y., Phang, X.Y., Su, M.H., Yek, P.N.Y., Ma, N.L., Cheng, C.K., Chong, C.T. \& Lam, S.S. 2018. Oil palm waste: An abundant and promising feedstock for microwave pyrolysis conversion into good quality biochar with potential multi-applications. Process Safety and Environmental Protection 115: 57-69.

Liu, C.F., Xu, F., Sun, J.X., Ren, J.L., Curling, S., Sun, R.C., Fowler, P. \& Baird, M.S. 2006. Physicochemical characterization of cellulose from perennial ryegrass leaves (Lolium perenne). Carbohydrate Research 341(16): 2677 2687.

Megha, R., Ravikiran, Y.T., Kotresh, S., Vijaya Kumari, S.C., Raj Prakash, H.G. \& Thomas, S. 2018. Carboxymethyl cellulose: An efficient material in enhancing alternating current conductivity of $\mathrm{HCl}$ doped polyaniline. Cellulose 25(2): 1147-1158.

Mondal, M.I.H., Yeasmin, M.S. \& Rahman, M.S. 2015. Preparation of food grade carboxymethyl cellulose from corn husk agrowaste. International Journal of Biological Macromolecules 79: 144-150.

Mousavi, S.M.S., Dehghanzadeh, R. \& Ebrahimi, S.M. 2017. Comparative analysis of ozonation (O3) and activated carbon catalyzed ozonation (ACCO) for destroying chlorophyll $\alpha$ and reducing dissolved organic carbon from a eutrophic water reservoir. Chemical Engineering Journal 314: 396-405

Moussa, I., Khiari, R., Moussa, A., Belgacem, M.N. \& Mhenni, M.F. 2019. Preparation and characterization of carboxymethyl cellulose with a high degree of substitution from agricultural wastes. Fibers and Polymers 20(5): $933-$ 943.

Malaysian Palm Oil Council. 2015. The Oil Palm Tree. Malaysian Palm Oil Council (MPOC). http://www.mpoc.org.my/ The Oil Palm Tree.aspx. Accessed 17 August 2020.

Naceur Abouloula, C., Rizwan, M., Selvanathan, V., Abdullah, C.I., Hassan, A., Yahya, R. \& Oueriagli, A. 2018. A novel application for oil palm empty fruit bunch: Extraction and modification of cellulose for solid polymer electrolyte. Ionics 24(12): 3827-3836.

Palamae, S., Dechatiwongse, P., Choorit, W., Chisti, Y. \& Prasertsan, P. 2017. Cellulose and hemicellulose recovery from oil palm empty fruit bunch (EFB) fibers and production of sugars from the fibers. Carbohydrate Polymers 155: 491-497.

Parid, D.M., Abd Rahman, N.A., Baharuddin, A.S., Mohammed, M.A.P., Johari, A.M. \& Razak, S.Z.A. 2018. Synthesis and characterization of carboxymethyl cellulose from oil palm empty fruit bunch stalk fibres. BioResources 13(1): 535-554

Panwar, N.L., Kothari, R. \& Tyagi, V.V. 2012. Thermo chemical conversion of biomass - Eco friendly energy routes. Renewable and Sustainable Energy Reviews 16(4): 18011816.
Pushpamalar, V., Langford, S.J., Ahmad, M. \& Lim, Y.Y. 2006. Optimization of reaction conditions for preparing carboxymethyl cellulose from sago waste. Carbohydrate Polymers 64(2): 312-318

Rachtanapun, P., Eitssayeam, S. \& Pengpat, K. 2010. Study of carboxymethyl cellulose from papaya peels as binder in ceramics. Advanced Materials Research 93-94: 17-21.

Rachtanapun, P., Luangkamin, S., Tanprasert, K. \& Suriyatem, R. 2012. Carboxymethyl cellulose film from durian rind. LWT - Food Science and Technology 48(1): 52-58.

Rachtanapun, P. \& Rattanapanone, N. 2011. Synthesis and characterization of carboxymethyl cellulose powder and films from Mimosa pigra. Journal of Applied Polymer Science 122(5): 3218-3226.

Sheikh, J., Bramhecha, I. \& Teli, M.D. 2015. Recycling of terry towel (cellulosic) waste into carboxymethyl cellulose (CMC) for textile printing. Fibers and Polymers 16(5): $1113-1118$

Shui, T., Feng, S., Chen, G., Li, A., Yuan, Z., Shui, H., Kuboki, T. \& Xu, C. 2017. Synthesis of sodium carboxymethyl cellulose using bleached crude cellulose fractionated from cornstalk. Biomass and Bioenergy 105: 51-58.

Soom, R.M., Ab Gapor, M.T. \& Hassan, W.H.W. 2004. Production of Carboxymethyl Cellulose (CMC) from oil palm Empty Fruit Bunch (EFB). MPOB TT 228: 235

Sophonputtanaphoca, S., Chutong, S. \& Nooeaid, K. 2019. Potential of Thai rice straw as a raw material for the synthesis of carboxymethyl cellulose. International Food Research Journal 26: 969-978.

Tasaso, P. 2015. Optimization of reaction conditions for synthesis of carboxymethyl cellulose from oil palm fronds. International Journal of Chemical Engineering and Applications 6(2): 101-104.

Tijsen, C.J., Kolk, H.J., Stamhuis, E.J. \& Beenackers, A.A.C.M. 2001. An experimental study on the carboxymethylation of granular potato starch in non-aqueous media. Carbohydrate Polymers 45(3): 219-226.

Tongdeesoontorn, W., Mauer, L.J., Wongruong, S., Sriburi, P. \& Rachtanapun, P. 2011. Effect of carboxymethyl cellulose concentration on physical properties of biodegradable cassava starch-based films. Chemistry Central Journal 5: 6 .

Togrul, H. \& Arslan, N. 2003. Production of carboxymethyl cellulose from sugar beet pulp cellulose and rheological behaviour of carboxymethyl cellulose. Carbohydrate Polymer 54(1): 73-82.

Varshney, V.K., Gupta, P.K., Naithani, S., Khullar, R., Bhatt, A. \& Soni, P.L. 2006. Carboxymethylation of $\alpha$-cellulose isolated from Lantana camara with respect to degree of substitution and rheological behavior. Carbohydrate Polymers 63(1): 40-45.

Yáñez, M., Matsuhiro, B., Maldonado, S., González, R., Luengo, J., Uyarte, O., Serafine, D., Moya, S., Romero, J., Torres, R. \& Kogan, M.J. 2018. Carboxymethylcellulose from 
bleached organosolv fibers of Eucalyptus nitens: Synthesis and physicochemical characterization. Cellulose 25(5): 2901-2914.

Yeasmin, M.S. \& Mondal, M.I.H. 2015. Synthesis of highly substituted carboxymethyl cellulose depending on cellulose particle size. International Journal of Biological Macromolecules 80: 725-731.

Youssef, M., Nada, A. \& Ibrahem, A. 1989. Effect of thermal-treatment on the reactivity of cellulose toward carboxymethylation. Cellulose Chemistry and Technology 23(5): 505-511.

Zafar, S. 2019. Biomass Wastes from Palm Oil Mills. BioEnergy Consult. https://www.bioenergyconsult.com/ tag/mesocarpfibers/\#: :text=Compared $\% 20$ to $\% 20$ other $\% 20$ residues $\% 20$ from,solid $\% 20$ fuels $\% 20$ for $\% 20$ steam $\% 20$ boilers.

Zhang, J. \& Wu, D. 1992. Characteristics of the aqueous solution of carboxymethyl starch ether. Journal of Applied Polymer Science 46(2): 369-374.
Nurul Suhada Ab Rasid, Muzakkir Mohammad Zainol \& Nor Aishah Saidina Amin*

Chemical Reaction Engineering Group (CREG)

School of Chemical and Energy Engineering

Faculty of Engineering

Universiti Teknologi Malaysia

81300 UTM Johor Bahru, Johor Darul Takzim

Malaysia

Muzakkir Mohammad Zainol

School of Chemical Engineering

College of Engineering

Universiti Teknologi MARA

40450 Shah Alam, Selangor Darul Ehsan

Malaysia

*Corresponding author; email: noraishah@cheme.utm.my

Received: 13 April 2020

Accepted: 27 January 2021 